\title{
A NEW TECHNIC IN PUNCH FORCEPS SCLEREC- TOMY FOR CHRONIC GLAUCOMA: TANGENTIAL AND EXTRALIMBAL IRIDENCLEISIS OPERATIONS EPITOMIZED I9I5-I9I9*
}

BY

\section{S. Holth \\ CHRISTIANIA}

THE many cases, published by various authors, of late infections after limbal sclerectomy, especially after sclero-corneal trephining, where, according to American operators, late infection occurs in about 7 per cent. of the cases (Lit. 8) induced me in 1915 to take up again two (Fig. 1 and 3) of the numeroust iridencleisis operations which I performed during the years 1904 to 1908 (Lit. 1, 2, 3, $4,7,11$ and 12). In both of these operations a subconjunctival tunnel is made to the limbus previous to the limbal keratome incision, either with scissors, or, still better and more elegant, with

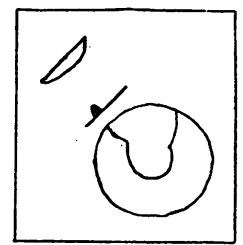

FIG. 1.

Iridencleisis simplex: used only in cases which have had an iridectomy previously performed.

the keratome itself (Lit. 3, Fig. 4), producing the subconjunctival tunnel during its progress into the anterior chamber.

A. Iridencleisis simplex: is used only in cases in which an iridectomy has been previously performed. The periphery of the iris at one border of the coloboma is drawn a little into the subconjunctival wound at one angle of the keratome incision (Fig. 1).

\footnotetext{
* Read at the Oxford Ophthalmological Congress, July 16, 1920, and at the Fifth Scandinavian Ophthalmological Congress at Stockholm, August 29, 1921.

$\dagger$ In Grimsdale and Brewerton's " Textbook of Ophthalmic Operations," Second Edition, 1920 (Lit. 10, p. 273), the following just observation is made about my paper of 1907 called " Iridencleisis antiglaucomatosa" (Lit. 3), " it gives so great a variety of methods that it is hardly possible to describe one single plan as Holth's method." To this observation, however, the reply must be given that the underlying principle was only one, viz., that of producing a fistula between the anterior chamber and the subconjunctival tissue by means of prolapsed iris. The least efficient operation was the iridotomy with a tongue shaped flap of the iris from the periphery turned backwards into the wound, the fistula being formed by the pillars of the coloboma protruding into the wound; these were frequently too small to produce the desired effect (I.it. 2, Fig. 6, and Lit. 3, Fig. 22). At that time I purposely tried several procedures in order to find the best method. I now think that the best methods are the two shown in the text above (Fig. 1 and Fig. 3). I should have recorded this some time ago if $I$ had not, in 1.908 introduced the punch forceps in doing limbal sclerectomy.
} 
B. Iridencleisis cum iridotomia meridionali: used for cases which have not been operated upon before. A subconjunctival keratome incision is made in the upper vertical meridian. The iris is seized with forceps at the margin of the pupil and drawn out so far that the upper border of the pupil appears outside the limbal incision. The assistant, by means of a blunt double hook (Fig. 2), draws down the conjunctival incision exposing the limbus; by this means the iris prolapse is laid bare.

The meridional iridotomy which includes $\mathrm{m}$. sphincter is best

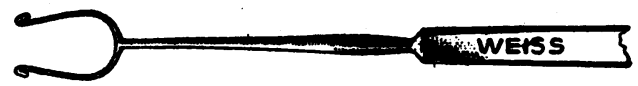

FIG. 2.

Dr. Holth's Double Conjunctival Blunt Hook (John Weiss' Catalogue No. 117 ;

No. 121, Dr. Holth's Fixation Forceps, elbowed, is very useful for all keratome incisions upwards.)

performed with Wecker's iris scissors, both blades of which have blunt ends. The lower blade is passed under the margin of the pupil as far back as the periphery of the prolapsed iris, which as soon as it rests on the blade of the scissors is released from the grasp of the forceps and the incision then made by closing the scissors. By this means scraping of the pigment epithelium from the back of the iris is avoided. The sphincter corners then spontaneously slide back into the anterior chamber, so that the periphery of the iris only remains in and a little outside the limbal incision (Fig. 3). I have very rarely been obliged to cut away any

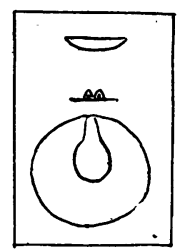

FIG. 3.

Iridencleisis cum iridotomia meridionali: used for cases which have not been operated upon before.

of the prolapsed iris tissue. The cut in the sphincter causes the original pupil, after re-establishment of the anterior chamber, to be considerably enlarged, and so optically nearly central (Fig. 3).

In the case of blind painful eyes in which the pupil is greatly enlarged in spite of miotics, I have, when the patient refuses enucleation, sometimes not made any incision in the iris but only left the edge of the pupil outside the limbal incision (Fig. 4).

It is this modification of my iridencleisis which J. Borthen calls "Iridotasis," an operation which I do not advise with a normally working $\mathrm{m}$. sphincter in an eye with good vision, because the pupil 
after the operation is drawn upwards, being displaced even to the limbus. The effect of these operations is not, as $\mathrm{Mr}$. Borthen believes, due to opening up the corneo-iridic angle by the pulling upwards of the iris-because this angle in most cases is open already before the operation. By microscopical examination post mortem of 13 eyes even with very advanced chronic glaucoma successfully operated with iridencleisis, as in Fig. 1 or 3, I have found the angle open in all meridians though the traction on the iris by these two proceedings is almost nil. On the other hand, in glaucoma absolutum and acute cases the periphery of the iris is frequently pressed against the back of the cornea. The lowering of tension by the operations is due to the following facts : the iris tissue embedded in the limbal wound produces in the successful cases a fistulous opening lined with pigment epithelium; this opening brings the anterior chamber into communication with the subconjunctival tissue. I wish to draw attention to the micro-photographs of iris fistula after iridencleisis which I published previously (Lit. 2, Fig. 3, Lit. 3, Fig. 10 and Lit. 7, Fig. 1), as well as to a paper "Anatomical Examination of Six

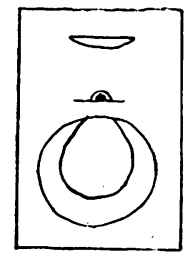

FIG. 4.

Iridotasis in glaucoma absolutum with a large pupil not affected by miotics.

New Cases of Subconjunctival Fistula Scars from five months to six years after Successful Iridencleisis or Limbal Sclerectomy in Chronic Glaucoma," which is shortly to be published in this journal. In other words, iridencleisis acts like limbal sclerectomy by the formation of a subconjunctival fistula. Lagrange (Lit. 9) designating colleagues who use iridencleisis "des operateurs qui n'ont adopté ni la théorie ni la pratique de la fistulisation" cannot have read my work of 1913 on the microscopical anatomy of fistula scars (Lit: 7). When, in connection with this, he suggests that the lowering of tension after iridencleisis is due to an iridocyclitis caused by the operation, I must answer him, on the basis of great experience, that he is utterly wrong, his only excuse being a complete ignorance of an operation which he has neither performed nor seen.

In my iridencleisis operations performed from 1904 to 1908 the subconjunctival incision was a bare millimetre from limbus (Lit. 3, p. 352). After 127 operations I had no case of late infection among seeing eyes, but I know of two cases of late infection after the lapse of many years in cases of glaucoma absolutum; one was mild 
and of short duration. In 1915, when taking up again iridencleisis, I soon found that the best results, with regard to the permanent lowering of the tension were obtained when the subconjunctival oblique keratome incision in the sclera was made $2 \mathrm{~mm}$. from the limbus (F1g. 1, 3, and 4). After iridencleisis with these peripheral subconjunctival incisions I have not yet seen any case of late infection; I believe the reason is that the conjunctival covering is thicker and has more blood vessels. I have had many good results of iridencleisis since 1915, among others, with a one-eyed colleague, who, four years after the operation, without miotics, has still V. $=5 / 5$ and normal tension. I must, however, admit that in some cases the tension has not become quite normal, even after the resumption of miotics. For this reason I have not been able to restrain myself from trying to find a possibly still better operation.

The idea struck me that perhaps a more peripheral sclerectomy fistula would be better protected against late infection than one close

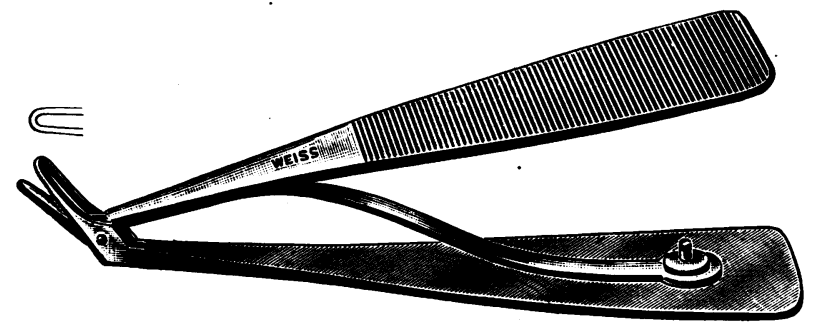

FIG. 5.

Holth's punch forceps, with blade $1 \mathrm{~mm} .^{*}$ for tangential extralimbal sclerectomy. Made by John Weiss \& Son, 287, Oxford Street, London, W. 48 .

to the limbus. The position of the sclerectomy close to the limbus could not be avoided in my two earlier operations with the punch forceps, removing pieces of sclera from the posterior or anterior lip of the wound (Lit. 5. Fig. 11 and 12; Lit. 6, Fig. 4 and 5). But by putting the $1 \mathrm{~mm}$. wide blade of my new punch forceps (Fig. 5) into the anterior chamber in tangential direction from a short incision, 1.5 or $2 \mathrm{~mm}$. from limbus, an extralimbal excision of the sclera can be obtained in the following way:

*This instrument is a modification of Dr. E. Forsmark's $2 \mathrm{~mm}$. wide punch forceps for sclerectomy of anterior lip of the wound. I have reduced the width of the handles and of the blades to $1 \mathrm{~mm}$. and made a change in the angle between handle and blade from $120^{\circ}$ to $135^{\circ}$; by this alteration the handle can be lowered without the temporal orbital margin getting in the way; thus the tangential sclerectomy is made more peripherally. The model may be bought at John Weiss \& Son, with $1.5 \mathrm{~mm}$. wide blades; I used this model in the first tangential sclerectomies. Though $I$ did not perceive any disadvantages, I believe, nevertheless, like Lagrange (Lit. 9) that a $1 \mathrm{~mm}$. wide excision is more convenient to the topography of the field of operation (Fig. 7). Till now I have found this $1 \mathrm{~mm}$. wide and $3 \mathrm{~mm}$. long excision is as efficacious in lowering the tension to normal as the $1.5 \mathrm{~mm}$. wide excision. I believe also that the narrower excision, which is naturally farther removed from limbus, gives the best protection against late infection. 
Before the anaesthesia the pupil should be well contracted by miotics. A large curved conjunctival flap $10 \mathrm{~mm}$. from the limbus with the apex somewhat temporally situated is dissected downwards to the limbus, but the ends of the incision should be at least $5 \mathrm{~mm}$. from the corneal margin (Fig. 6).

An incision 3 or $4 \mathrm{~mm}$. long is made into the anterior chamber; this is best performed with the keratome* ; the point of the knife is inserted 1.5 to $2 \mathrm{~mm}$. from limbus and $3 \mathrm{~mm}$. temporally to the vertical meridian. Before the point of the keratome reaches the chamber, the conjunctival flap is turned upwards from the cornea in order that the point of the knife may be seen in the angle of the chamber; during this proceeding a good electric sidelight ought always to be used. In removing the keratome from the anterior chamber the handle is lowered and the point turned sideways; in

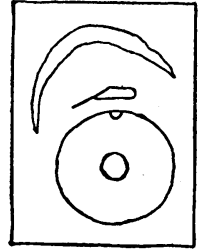

A

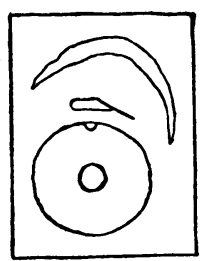

B

Showing the incision in the conjunctiva and sclera in the right and left eyes-somewhat outside the upper vertical meridian. The tangential and extralimbal sclerectomy is shown at the inner end of the keratome incision in the sclera. A small basal iridectomy has been performed. Instead of a conjunctival flap a subconjunctival tunnel may be made to the limbus as in Fig. 1 or 3 ; then an assistant, by means of the blunt double hook (Fig. 2), draws down the conjunctival incision exposing the limbus for sclerectomy and basal iridectomy.

this way any danger of wounding the lens capsule is avoided. The operator now takes his stand behind the head of the recumbent patient whether the sclerectomy is to be made on the right or the left eye. The $1 \mathrm{~mm}$. wide blade of the punch forceps is, with the flat part parallel with the sclera in tangential direction, introduced below the nasal angle of the wound $3 \mathrm{~mm}$. into the anterior chamber. In order to make the scleral opening oblique and so place it farther from limbus, the handle is lowered till it forms an angle of about $150^{\circ}$ with the plane of the iris (see the punctuated lines in Fig. 7).

*For all keratome incisions upwards I stand before the patient, hold the handle with palmarflected slightly supinated hand and guide the point towards me; in removing the keratome I have plenty of free movement of the hand for lowering the handle and turning the point sideways in order to avoid any wounding of the lens capsule. By standing behind the head of the patient and holding the handle with dorsalflected and pronated hand, thus guiding the point from him, the operator has very limited hand movement (see W. Czermak "Augenärztliche Operationen," Wien 1893-1904, p. 10, Fig. 13). For all subconjunctival glaucoma operations the blades of the speculum ought to be short in transversal direction. By this means the palpebral fissure can be well opened in vertical direction and plenty of space be obtained for making a conjunctival flap or a subconjunctival tunnel. 
The piece of sclera is now excised by closing the punch forceps ; it should be $3 \mathrm{~mm}$. long and the anterior edge should be placed rather more than $1 \mathrm{~mm}$. from the limbus. A small basal iridectomy is then performed; but in some cases, such as where the iris has completely prolapsed, or in some cases of cataract, a complete iridectomy is done. The conjunctival wound is then sutured with three fine black silk threads which are tied only with the first half of a surgical knot and removed after forty-eight hours.

For the left eye the punch forceps ought to be held in the left hand if the operator stands behind the patient ; but if he wants to use his right hand he should stand before the patient, preferably on

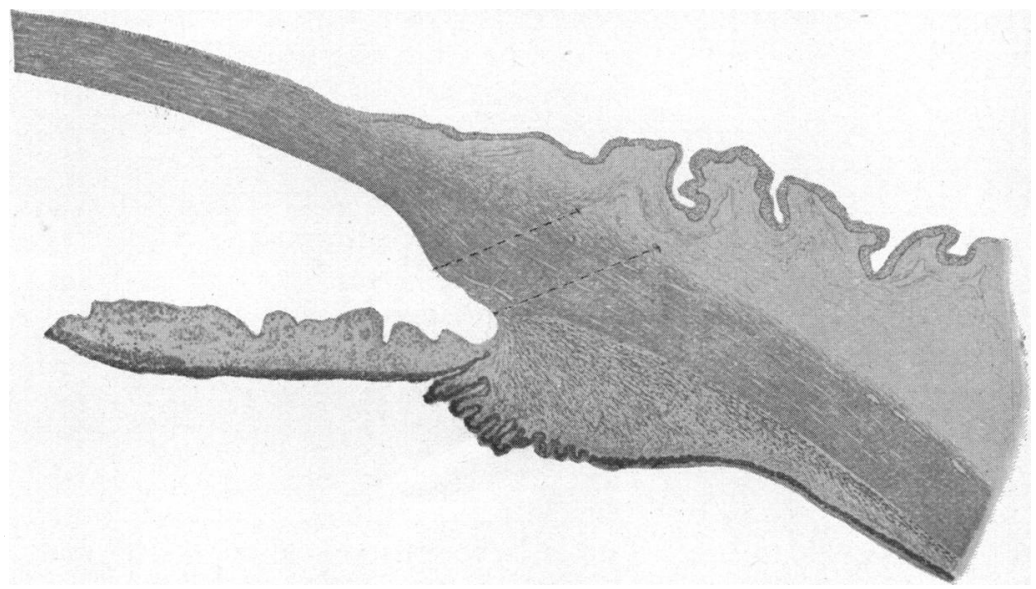

FIG. 7.

The punctuated lines show the position, limits, and direction of the tangential, extralimbal $1 \mathrm{~mm}$. wide punch forceps sclerectomy; in the removed scleral piece is a little of canalis Schlemmii and of the ciliary muscle tendon, while the ciliary body itself is not laid bare.

the right side. If the keratome incision in the left eye is made to the nasal side, he may remain standing behind the patient and with his right hand make tangential sclerectomy to the temporal side; a protruding forehead would, however, during this proceeding present difficulties to the lowering of the handle of the punch forceps.

If the patient be a squeezer a transitory paralysis of the m. orbicularis after van Lint (1914) should be made previously by injection of a 2 per cent novocain solution with adrenalin freshly made with tablets. If the patient constantly turns the eye up, a transitory paralysis of the m. rectus superior may be made previously by injecting $0.5 \mathrm{ccm}$. of the same solution in the muscle (G. F. Rochat, 1920).

This operation, which I have used since March, 1920, has, up till now (August, 1921) yielded at least as good tension lowering results as my old sclerectomies or as sclero-corneal trephining. As 
after all these operations, frequent appearance of post-operative transitory choroidal detachment is liable to occur and may last for four weeks, seldom more. Sigurd Hagen found it in 76 per cent, after Elliot's operation (Lit. 14, p. 171). I cannot state the frequency of this complication after the tangential sclerectomy, not having used the method of diagnosis discovered by Hagen (Lit. 14, Fig. 1 and 2), viz., increased transparence of sclera by electric transillumination a few days after the operation. I operated on a foreign colleague on December 20,1920; a large bag-shaped temporal detachment of the choroid soon appeared. It had not altered when he left Christiania on January 18; on July 1 he wrote to me that the detachment had disappeared in the course of a few days about February 24,.and that the sight of the eye had been excellent ever since.

Whether iridencleisis or sclerectomy should be performed in chronic glaucoma cannot easily be, decided beforehand. After secondary iridencleisis I have several times obtained better results than I had obtained by any form of primary sclerectomy; in other cases, secondary sclerectomy has given the best results. I believe that the operator for glaucoma would do right in not forgetting either of these operations; but they should not be combined, an idea I suggested at Heidelberg in 1913 (Lit. 7, p. 213) ; the ophthalmic surgeon should study the results of each operation separately.

In primary acute glaucoma I prefer the classical iridectomy; only when this operation fails, and chronic glaucoma develops afterwards and is not influenced by miotics, I perform iridencleisis (Fig. 1) or sclerectomy as re-operation. In cases of chronic glaucoma with some acute phenomena, e.g., redness of the conjunctiva, hazy cornea and rainbows around the light, I have repeatedly had better results with iridencleisis (Fig. 1 or 3) than with iridectomy or any form of sclerectomy. In secondary glaucoma-mainly in iridocyclitis-neither iridencleisis nor sclerectomies give permanent results; iridectomy and medicamentous treatment are, as a rule, better.

The advantages of the tangential punch forceps sclerectomy are the following :

1. A short incision, 3 or $4 \mathrm{~mm}$.; a shallow chamber does not form any contra-indication, as a very oblique incision does not prevent the tangential introduction of the $1 \mathrm{~mm}$. wide punch forceps blade.

2. The scleral excision $1 \times 3 \mathrm{~mm}$. is made easily and quickly without any pressure on the globe.

3. The anterior wall of the scleral opening is parallel with the posterior wall (Fig. 7), the walls do not converge inwards as in my old sclerectomies. 
4. The excision does not remove any cornea, it removes a piece of sclera only, including Descemet's membrane, the canal of Schlemm and some of the insertion of the ciliary muscle; it does not lay bare the ciliary body itself. (Fig. 7).

5. The defect is covered by thicker and better vascularized conjunctiva than in my old sclerectomies and has a similar advantage over the sclero-corneal trephining. I have not up till now seen the thin glassy bubble over the opening; frequently a flat cushion appears in the conjunctiva, with surrounding diffuse oedema; this is increased by massage, and both of them may disappear without any increase of the tension.

On these accounts I believe I am justified in hoping that late infections after the tangential extra limbal punch forceps sclerectomy will be very rare; time will show if they can be completely avoided.

\section{LITERATURE}

1. Holth, S. - "Discussion sur la sclérécto-iridectomie de Lagrange." Bull. et mémoires de la Société française d'Ophtal., 1906, pp. 492-495.

2. Holth, S. - "Ein neues Prinzip der operativen Behandlung des Glaukoms." Bericht d. Ophthal. Gesellschaft, Heidelberg, 1906, pp. 123-128.

3. Holth, S. - "Iridencleisis antiglaucomatosa." Ann. d'Ocul., 1907, Vol. CXXXVII, pp. 345-375.

4. Holth, S. - "De l'action favorable de l'iridencleisis dans les cas de glaucome chronique où l'iridectomie et la sclérotomie sont restées insuffisantes." XI Congresso internationale di Oftal., Napoli 2-7, Aprıl, 1909, Fascicolo primo, pp. 245-250.

5. Holth, S. - "Scléréctomie antérieure à l'emporte-pièce dans le glaucome, de préférence après incision à la pique." Bull. et Mémoires de la Sociéte française d'Ophtal., 1909, pp. 326-340 and Ann. d'Ocul., 1909, Vol. CXLII, p. 1 .

6. Holth, S. - "On my technique in Limbal Sclerectomy for Glaucoma." The Oxford Ophthalmological Congress, July, 1910. The Ophthalmoscope, 1911, pp. 487-494.

7. Holth, S. - "Anatomische Untersuchung der Operationsnarben und der aplanierten Papillenexkavation nach erfolgreichen Glaukomoperationen (Iridencleisis, Sclerectomia limbalis nach Holth oder Elliot, Sclerectoiridencleisis)." Bericht d. Ophth. Gesellschaft, Heidelberg, 1913, pp. 355-370.

8. Fuchs, E.- "Text-Book of Ophthalmology." 6th American Edition. By Alexander Duane. Philadelphia, 1919, p. 512.

9. Lagrange, F.- "Des opérations décompressives dans le traitement du glaucome chronique." Communication faite à la Société belge d'Ophtalmologie, séance du 30 novembre, 1919.

10. Grimsdale, Harold and Brewerton, Elmore.-." A Text-Book of Ophthalmic Operations." Second Edition. London, 1920, p. 373.

11. Holth, S. - " Mikroskopiske præparater av limbale fistelarr efter iridencleisis og efter sclerectomia limbalis " (series of preparations from four operated eyes). Oft.ll. forening $i$ Kristiania, 6 March, 1916.

12. Holth, S.- "Conjunctiva's forhold ved fistelarr efter iridencleisis og efter sclerectomi." Seven preparations. Ibidem, 25 September, 1916.

13. Holth, S. - "Mikroskropiske præparater av sclerectomiarr efter Elliot's operation." Ibidem, 30 April, 1917. (No. 11-13 in Tidsskrift for Den norske Lageforening, No. 22, 1919).

14. Hagen, Sigurd.- "Die seröse postoperative Chorioidealablösung und ihre Pathogenese." Klin. Monatsbl.f. Augenheilk., 1921, Vol. LXVI, pp. 161211. 